\title{
電場印加時における液晶流動の可視化と产の応用*
}

\author{
築地 徹浩**
}

\section{Visualization and Application of Liquid Crystal Flow under Application of Voltages}

\author{
Tetsuhiro TsukiJI
}

\section{1.はじめに}

液晶は，我々の身の回りでよく見られるが，液晶の流 動については意外と知られていない。液晶をいわゆる機 能性流体としてとらえた場合, 電場及び磁場にも反応す ることは，他の機能性流体に見られない液晶の特徵の一 つである，他に，液晶は機能性流体として次のような特 徴を持っている，1．粒子が無い均一系流体である，2． 可逆性がある。 3 。応答性が良い。(数 ms) 4 ，正や 負の誘電率異方性や磁化率異方性を持っている，5. ニュートン流動（ネマティック液晶）やビンガム流動 (スメクティック液晶) を示す。これらのほとんどの特 徵は, 液晶の配向変化などに起因する電界効果形に属す る現象であり，よく知られている。ここでは，先ず本実 験で用いた液晶や他の機能性流体の物性值について説明 し，一様電場印加時での平行平板電極間の対流現象の可 視化結果を述べ，次に非一樣電場強度における誘電泳動 （Dielectrophoresis）に関していくつかの可視化結果を 示し，液晶の誘電泳動現象について述べる。ささらに，試 作した円筒電極内での矩形波電圧や三相正弦波電圧を用 いた回転電場による液晶の回転流動について説明し, 最 後にこの回転流動を利用したモータやポンプなどへの応 用例を示す。

\section{2. 基本的流れ場での流動}

\section{1 液晶の物性值}

今回使用した液晶は,メルク侏製のネマティック液晶 (K-15) およびそれらの数種類を混合した混合液晶 (MLC 6650, MJ 0669) である.さらに, 比較のため, 一般に, EHD (Electrohydrodynamics) 現象を示すと いわれているセバシン酸ジブチル (DIBUTYL SEBACATE (DBS) ) および誘電泳動現象を示す二種 類のフロリナート（FC 70, FC 77）を使用した。 MJ 0669 から K 15，MLC 6650 の順に動粘度 $\left(20^{\circ} \mathrm{C}\right)$

* 原稿受付 2007 年 1 月 19 日

** 正会員上智大学理工学部機械工学科 ( 7 102-8554 東京 都千代田区紀尾井町 7-1, E-mail : t-tukiji@ Sophia.ac.jp)
は $13 \mathrm{~mm}^{2} / \mathrm{s}, 20 \mathrm{~mm}^{2} / \mathrm{s}, 76 \mathrm{~mm}^{2} / \mathrm{s}$ で, 誘電率（液晶 分子の軸方向を $\varepsilon$ 軸，垂直方向を $\varepsilon$ 垂直）は同順で， $\varepsilon$ 軸；11.2，26.1，62.8， $\varepsilon$ 垂直；3.9，6.0，10.2であ る。フロリナート FC 70 (誘電率 1.98) と FC 77 (誘 電率 1.86) の動粘度は $13.4 \mathrm{~mm}^{2} / \mathrm{s}\left(25^{\circ} \mathrm{C}\right)$ と 0.8 $\mathrm{mm}^{2} / \mathrm{s}\left(25^{\circ} \mathrm{C}\right)$ である.

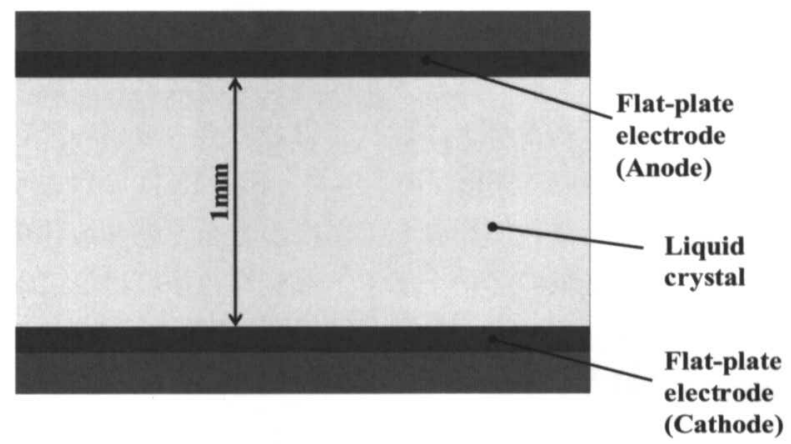

Fig. 1 Parallel plate electrodes

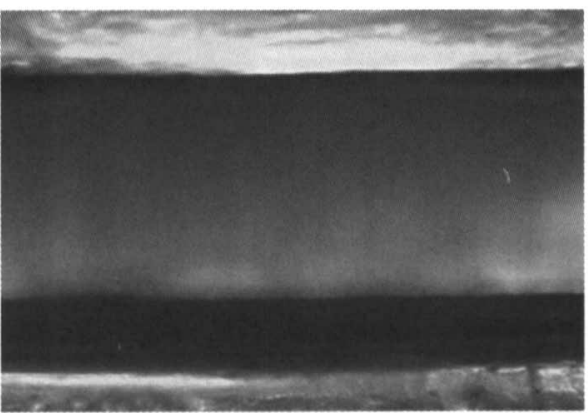

Fig. 2 Visualized result

\section{2 平行平板電極間内の流動}

Fig. 1 に示すようなギャップ $1 \mathrm{~mm} の$ 平行平板電極 間に混合液晶（MCL 6650）を入れ，直流 $3 \mathrm{kV}$ を印加 して一様電場のもとで流動を観察した。可視化結果を Fig. 2 に示す. 図中の電極間に見られる電場方向の筋が 複雑に動き，電極間で不規則な対流が観察された。電場 強度の増加とともに速く複雑な流動が見られた。これは, 一般に電気流体力学的不安定 (EHD instability) と呼 
ばれているような流動であり, 今後, 高速度カメラを用 いてもっと詳細に調べる必要がある。

\section{3 非一様電場強度での流動}

Fig. 3 に示すような左側が電場強度が大きい流れ場を 作り誘電泳動を示す流体を電極間におくと, 電場強度が 大きい細い流路の方向に流れる ${ }^{1}$. 液晶 MJ 0669 を用い て, 3 kVDC を印加した場合の可視化結果を Fig. 4 に示 す. Fig. 4(a)では液晶の自由表面は下の方にあるが電場 印加後, 時間が経過した Fig. 4 (b)では上方向 (Fig. 3 の 左方向）に流れている。なお，交流でも同様の現象が見 られた。

容器の底と底から $1 \mathrm{~mm}$ 離して垂直に立てた棒状の 電極を用いて Fig. 5 に示すような非一様な電場の状態

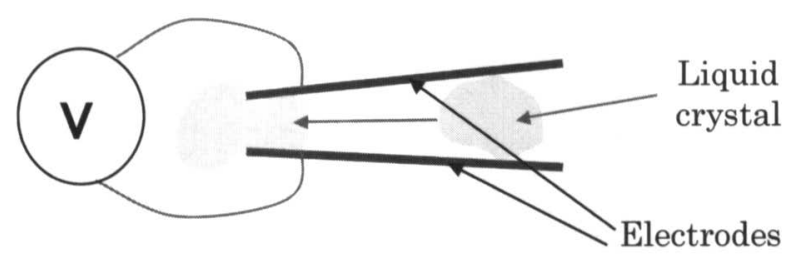

Fig. 3 Dielectrophoresis (DEP)

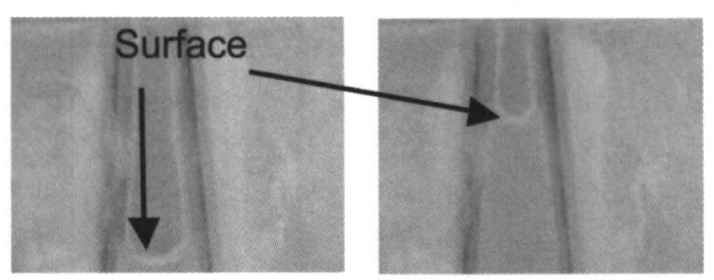

(a) No field

(b) Under voltage

Fig. 4 Observed results (MJ 0669, 3 kVDC)

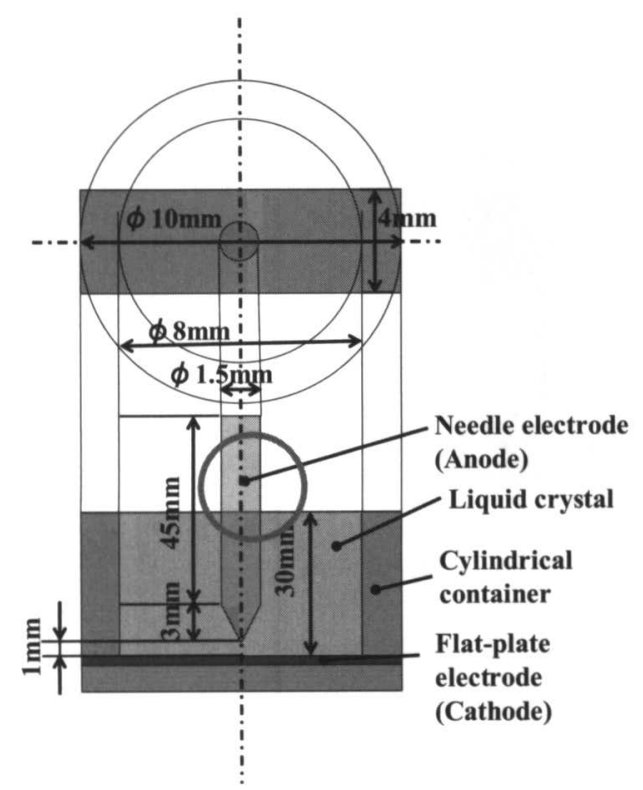

Fig. 5 Non uniform electric field

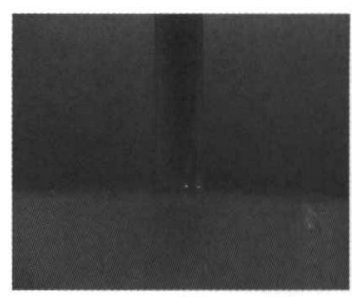

(a) No field (b) Under voltage

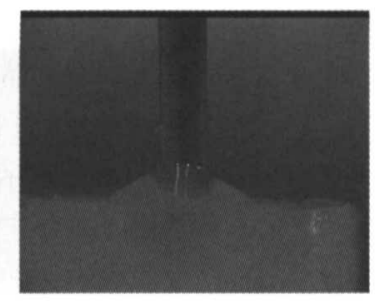

Fig. 6 Visualized results (MLC 6650, 3 kVDC)

を作り電極の自由表面付近（Fig. 5 の丸印付近）の流れ を観察した2). 可視化結果を Fig. 6 に示す. MLC 6650 の液晶を使用し， $3 \mathrm{kVDC}$ を印加した場合である。無電 場状態を Fig. 6 (a)に示し, 電場印加後を Fig. 6 (b)に示 す. 電場強度が強い部分に液晶が集まり, 自由表面の電 極付近で液晶が盛り上がっていることが分かる。ここで は見えないが, 液晶表面下の棒電極付近で複雑な流動が 観察された.

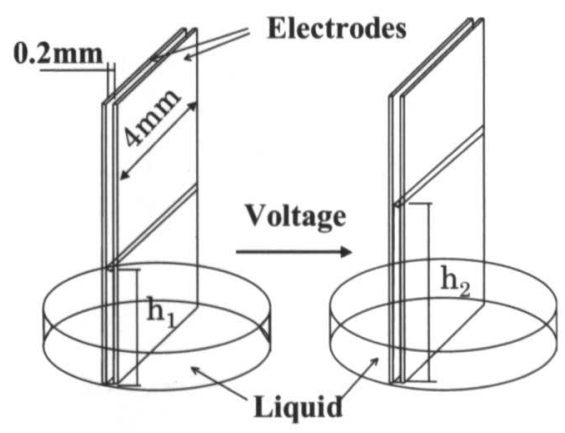

Fig. 7 Parallel plate electrodes

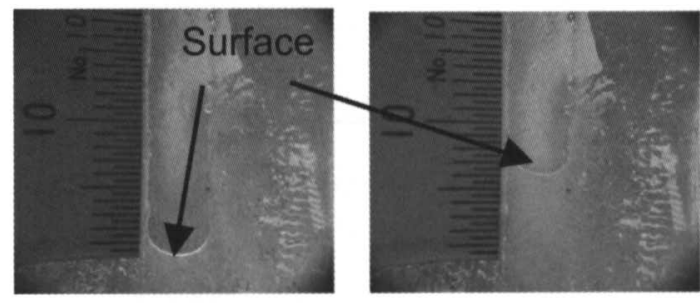

$\begin{array}{ll}\text { (a) No field } & \text { (b) Under voltage }\end{array}$

Fig. 8 Visualized results (MJ 0669)

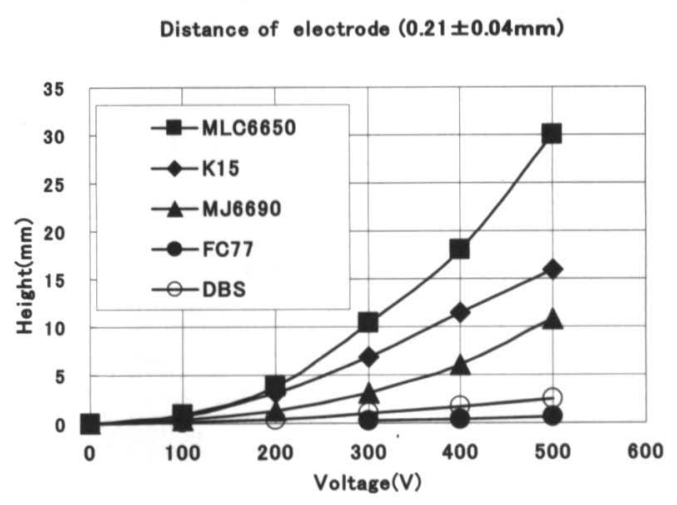

Fig. 9 Height of the surface 
さらに，二枚の透明電極を用いて Fig. 7に示すよう な可視化装置を作り，液晶の上昇を観察した3)。液晶 MJ 0669 を用いた場合の可視化結果をFig. 8 に示す.

Fig. 8 (a)が無電場の場合を示し, 電場を印加した場合が Fig. 8(b)で液面が上昇しており, 誘電泳動現象を示して いる。この電場が液面の高さに及ぼす影響を Fig. 9 に 示す、参考のために EHD 流体の一つであるセバシン酸 ジブチルとフロリナート (FC 77) の結果も示す. 誘電 率が大きいほど液面が高く，電場に対する液面の高さの 変化は二次曲線的である. 誘電泳動流体であるフロリ ナートよりも液晶の方が液面が上昇する．以上のように, 液晶は誘電泳動現象を示し, その効果はセバシン酸ジブ チルやフロリナートより大きいことが分かる。

\section{3. 回転電場による円筒電極内での回転流動}

\section{1 矩形波回転電場印加実験}

Fig. 10 に示すような円筒電極を製作し，回転電場を 印加することで回転流動を引き起こすことを試みな4. 使用した液晶は，混合液晶 MLC 6650 である。この円 筒電極は, 深さ $h=2 \mathrm{~mm}$, 内径 $1.1 \mathrm{~mm}$ で, 内壁に 0 . $2 \mathrm{~mm}$ の間隔で絶縁された 6 個の電極を有している．液 晶流動は, 電場強度の大きい部分で激しく生じる.その 現象が顕著に現れるようにっこのような小型の

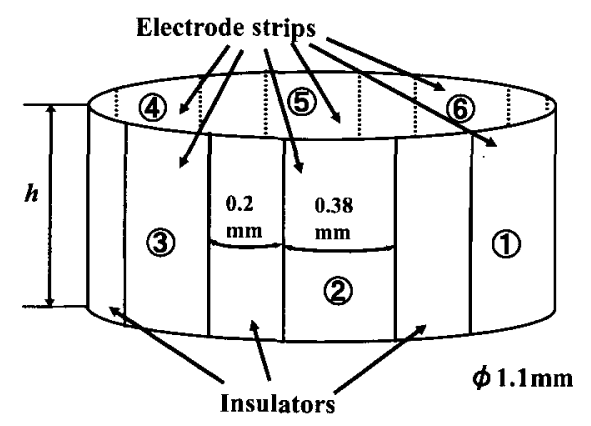

Fig. 10 Cylindrical electrode $(h=2 \mathrm{~mm})$
Cylindrical-type の電極を作成した。円筒電極の6 極に 対して周方向に順々に直流矩形波電圧を印加する。電圧 は200Vで一定とし，周波数を変化させた。ここでい う周波数とは，1秒間に, 印加電圧の場所が移動する回 数（例えば， $6 \mathrm{~Hz}$ なら印加電圧の場所が 1 秒で 1 周す

\section{る)である。}

矩形波電压を発生させる装置全体の概要を Fig. 11 に 示す.まず, 信号発生器(D)から任意の周波数の矩形波 （電圧は土 $5 \mathrm{~V}$ で一定）を回転電場発生装置(F)に入力す ることで周波数を決定する（例えば， $60 \mathrm{~Hz}$ の矩形波を 回転電場発生装置(F)に入力したら，電場は 1 秒間に 60 回移動 (10 回転) 方る. 次に, 電力増幅器 (パワーア ンプ) (E)から，任意の電圧の直流電圧を回転電場発生装 置(F)に入力する。ここで入力される電圧の值が, 回転電 場発生装置 $(\mathrm{F})$ から出力される電圧の值となる。例えば, 電力增幅器 (パワーアンプ) (E)から回転電場発生装置 $(\mathrm{F})$ に直流 $200 \mathrm{~V}$ を入力すると, 回転電場発生装置(F)から 出力される電压も $200 \mathrm{~V}$ とな。 つまり, 回転電場の 周波数は, 信号発生器(D)により出力された矩形波の周波 数に一致し, 回転電場の電圧は電力増幅器(E)の電圧に一 致する，回転電場発生装置(F)から出力された電圧が，円 筒電極 $(\mathrm{J})$ に印加される。筒電極 $(\mathrm{J})$ に液晶 MLC 6650 を満たし，鉛直方向から撮影し，DVデッキにて録画，

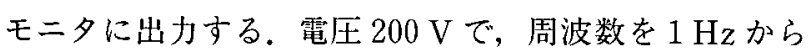
$200 \mathrm{~Hz}$ まで增加させていき，それぞれの周波数におけ

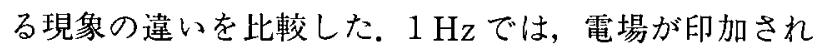
た電極間において，瞬間的に激しい流動が観察された。 印加される電極が周方向時計回りに移動していく様子も, 液晶の流動から確認できた. その代表的な様子を Fig. 12 に示す. $10 \sim 100 \mathrm{~Hz}$ においては, 円筒容器内の液唱 表面の中心付近で液晶が振動し，その外側では不規則に 流動するという現象が起こった. $100 \mathrm{~Hz}$ 以上では, 液 晶全体が円筒軸中心に対して時計方向（電場の回転方 向）に回転する流動を引き起こすことが分かった。この

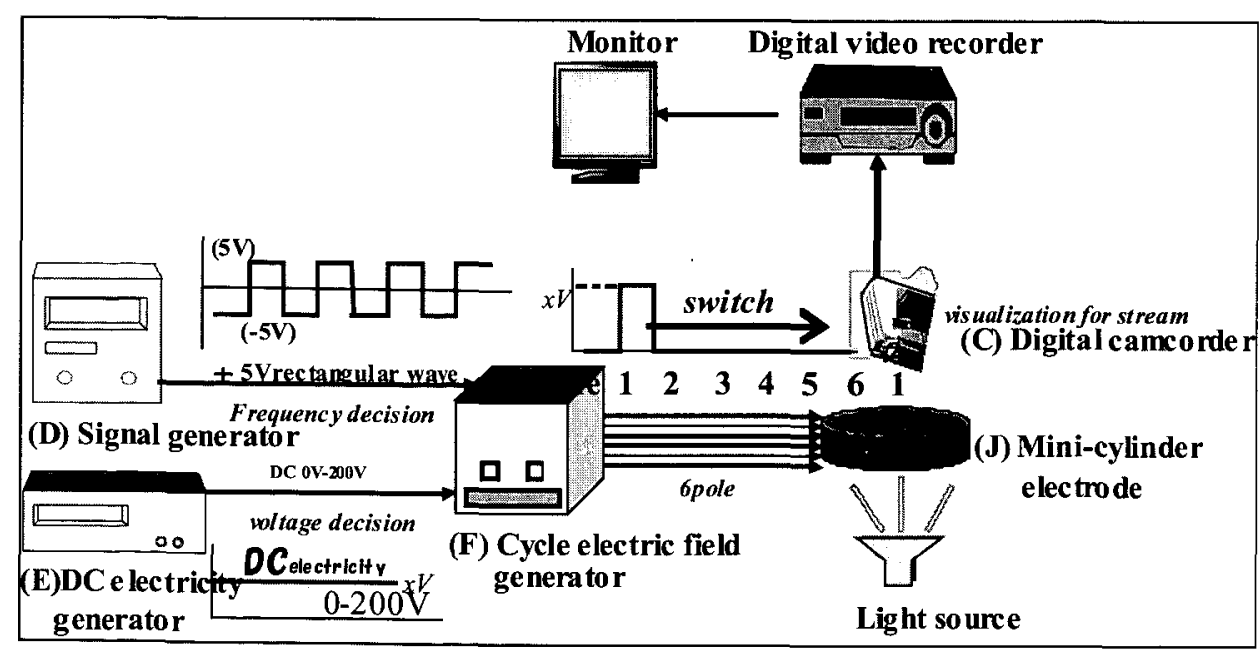

Fig. 11 Experimental apparatus 


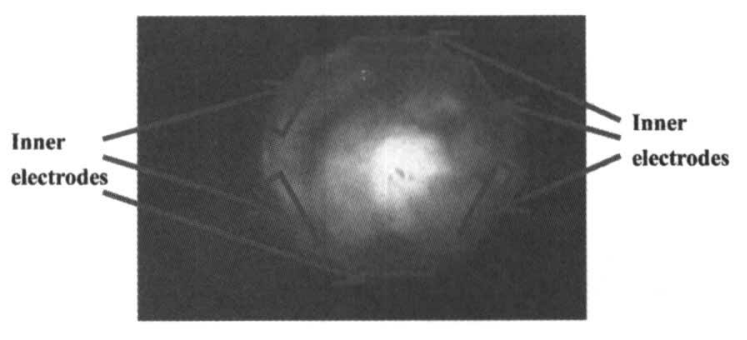

Fig. 12 Flow visualization result

ときの回転数を, 撮影した映像内の半径 $0.25 \mathrm{~mm}$ あた りの円周上を動く気泡が一回転に要する時間を 5 回測定 し, 平均をとることで求めた. その結果を Fig. 13 に示 す. 流動回転数は $100 \mathrm{~Hz}$ において 0.95 r.p.m.であり, $200 \mathrm{~Hz}$ で1.24 r.p.m.であった.

\section{2 三相正弦波電圧印加実験}

3.1 節で述べたように，矩形波電圧を用いた回転電場 によって, 電場の回転速度に対しては遅いが回転流動が 得られた。 そこで, 連続的に回転電場を引き起こす三相 正弦波電圧を用いた実験を行なった. Fig. 10 に示す円 筒電極の向かい合う電極を等電位とし， 3 組に対して三 相正弦波電圧を印加する. 三相正弦波とは起電力, 周波 数がともに同一であり, 位相が $2 / 3 \pi\left(120^{\circ}\right)$ ずつ異な る 3 個の交流起電力 (単相正弦波) を一組にしたもので

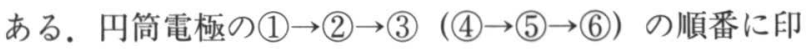
加することで, 電場が右回りに回転しているような状態 を作り出す.この場合の流動回転数の測定結果を Fig. 14 に示す。電圧値は, 実効値を示す. 三相正弦波電圧 を液晶 MLC 6650 に印加することで, 矩形波電圧印加

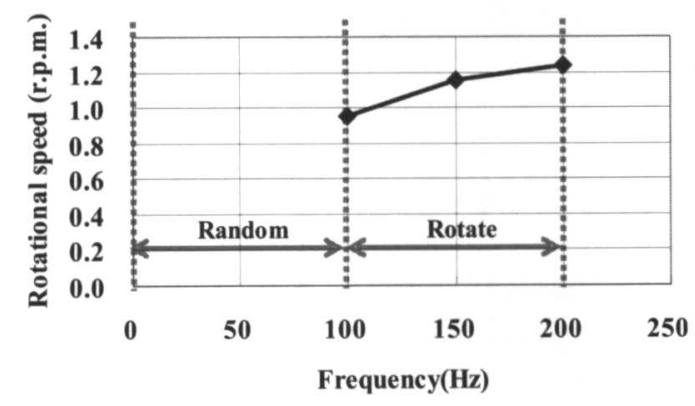

Fig. 13 Rotational speed

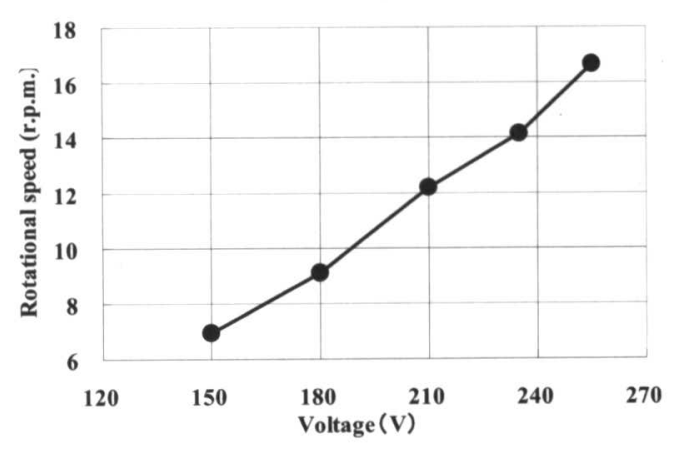

Fig. 14 Rotational speed
時よりも回転数の大きい回転流動を引き起こすことがて きた，電圧を上昇させると，液晶は $1 \sim 150 \mathrm{~V} て ゙$ 小く 不規則にに流動し, $150 \mathrm{~V}$ 付近から回転流動を始める. これ以降, 電圧を上げると混合液晶の回転数も増加する という結果が得られた.

Fig. 15 の左図は電圧 $255 \mathrm{~V}$ における可視化結果の一 例を示している.また，右図はその結果に PIV 処理を 施したものである.これは, 流れの方向を全体的に把握 するために平滑化したものである.この結果から, 混合 液晶が時計方向（電場の回転方向）に回転している様子 が分かる.
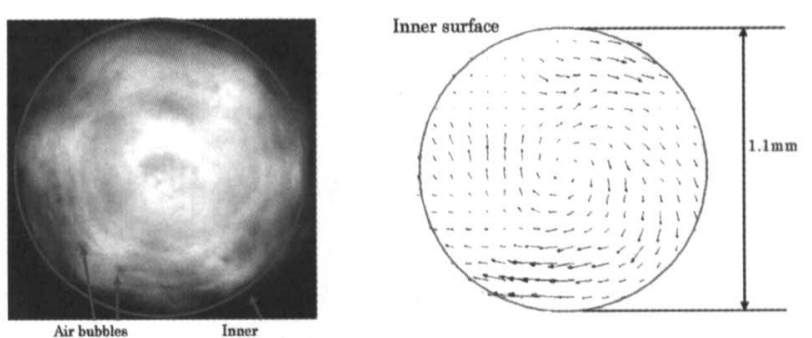

Fig. 15 Flow under rotational voltage

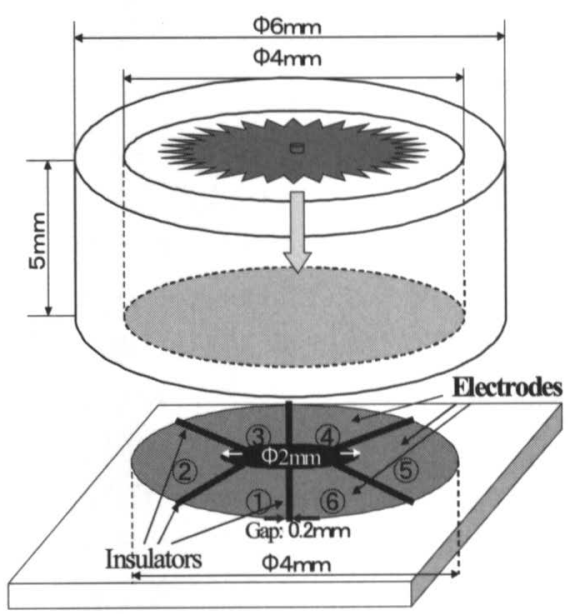

Fig. 16 Liquid crystal motor

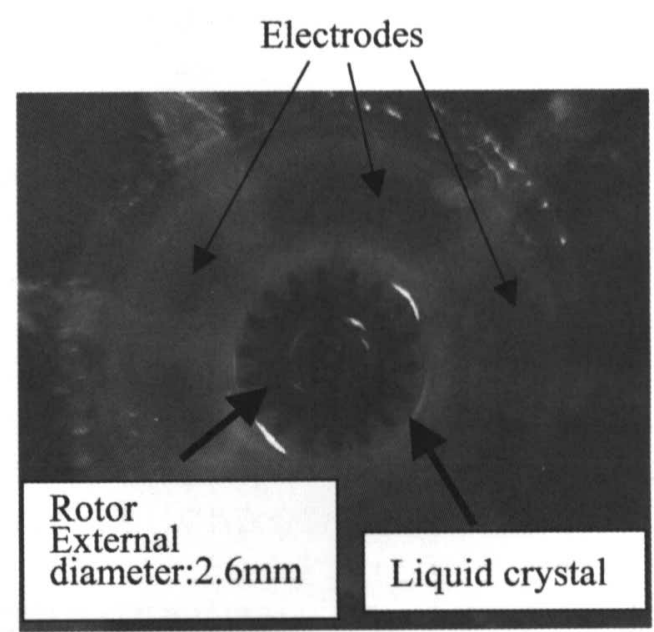

Fig. 17 Photo of motor 


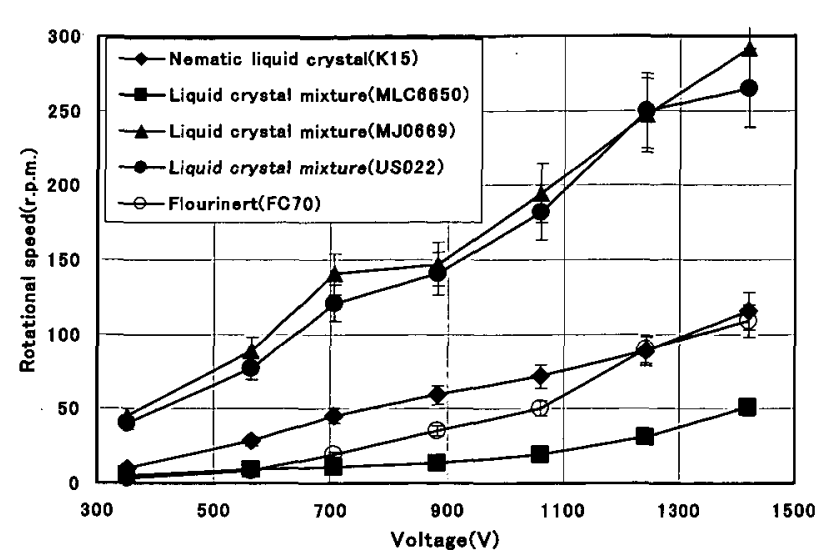

Fig. 18 Rotational speed for various fluids

\section{4. 液晶モータと液晶ポンプ}

\section{1 液晶モータ}

本実験で用いた液晶モー夕の概要を Fig. 16 に示寸. 絶縁性の冈筒は深さ $5 \mathrm{~mm}$, 内径 $4 \mathrm{~mm}$ であり, 底面に 6 枚の電極が $0.2 \mathrm{~mm}$ の間隔で配置されている。この 円筒内に機能性流体を哚さ $2 \mathrm{~mm}$ まで注入し，さらに 流体内に直径 $2.6 \mathrm{~mm}$, 軸方向長さ $1.5 \mathrm{~mm}$ のロー夕 （Fig. 17 参照）を入れる。本モータでは,電場印加時の 機能性流体の回転流動によってロータが回転する，3 章 で述べた円筒形状の円筒電極を用いたモー夕も試作した が, Fig.16に示すようなディスクプレートタイプの方 の回転数が大きかったので今回はディスクプレートタイ プのモータの結果を示す、ロータをビデオカメラで軸方 向から撮影することによって回転数を計測した。

本電場印加装置では周波数 $50 \mathrm{~Hz}$, 電圧寒効値 $170 \mathrm{~V}$ の三相正弦波電圧をスライダックに入力し，このスライ ダックにより 0 240 Vの範囲で出力電圧を設定する. 次に，トランスに入力することで電圧の振幅を約 15 倍 に増幅し，電極に印加する，本実験では周波数を一定の $50 \mathrm{~Hz}$ にし, 電圧の実效值を変化させ, 電圧がロー夕の 回転数に与える影響を調べた。

4 種類の液晶とフロリナート（FC 70）を使用流体と して用いた場合の電压とロータ回転数の関係を Fig. 18 に示す。ここで, 液晶 US 022 は, ベース液晶 MJ 0669 にカイラル剤を $0.22 \%$ 添加し，ピッチ長 $60 \mu \mathrm{m}$ に調製 したカイラルネマティック液晶である。なお，本実験で は機能性流体内のロー夕を上部から撮影することによっ て回転数を 5 回計测し, 計測值を平均することによって 評価している。また，口ータがほほ回転しない電圧 300 $\mathrm{V}$ 以下の範囲は省略し，353 V - 1420 V の範囲を回転数 計測の対象とした，本実験の範囲において，周波数を一 定にして電圧を増加させると, ロー夕回転数も増加する ことが Fig. 18 から分かる。混合液晶 MJ 0669 使用時に ロータ回転数が最も大きいことが分かった，カイラル剤 の影響はほとんど無かった。 4 種類の液晶に関して，動 粘度及び誘電率が低い液晶を用いた場合の回転数は大き
くなるという傾向が見られたが，現時点ではどの特性が 回転数に影響を及ほすかは分かっていない。

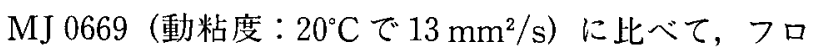
リナート $\left(\mathrm{FC} 70: 25^{\circ} \mathrm{C} て ゙ ~ 13.4 \mathrm{~mm}^{2} / \mathrm{s}\right.$, 誘電率 $\left.; 1.98\right)$ の回転数は, $50 \%$ 未満であった。

\section{2 液晶ポンプ6)}

試作された液晶ポンプを Fig. 19 に示す. Fig. 10 に示 すような冈筒電極を外側に有する内部流路の巻き数が 3 のポンプであり, 軸方向長さ $h$ は $15 \mathrm{~mm}$, 電極幅は 1 . $2 \mathrm{~mm}$, 電極閒距離は $0.9 \mathrm{~mm}$ で 9 個の電極を有してい る. 流路幅 $\mathrm{w} は, 1 \mathrm{~mm}$ と $3 \mathrm{~mm}$ の二種類について実 験を行なった。この電極に三相交流電圧を印加すること により混合液晶 MLC 6650 の回転流動を得ることがで きる.さらに，この回転流動により，液晶は螺旋状の流 路を流れるため軸方向に流れる.

実験装置の全体図を Fig. 20 に示す。三相交流 $50 \mathrm{~Hz}$, $200 \mathrm{~V}$ をトランスにより増幅させポンプの電極に印加す るＵU字管の差圧を読み取ることにより圧力を計測す る.

結果の一例として, 流路幅が 1 および $3 \mathrm{~mm}$ の場合 の電圧と圧力の関係を Fig. 21 に示寸. 圧力は, 流路幅 $\mathrm{w}$ の影響をほぼ受けてなく, 電圧の増加ととも二次曲 線的に上昇することが分かる．いくつかの液晶で同様の 実験を行なったが, 粘度や誘電率が大きい混合液晶 MLC 6650 が最も圧力が高かった。これは，モー夕の回 転数の増減の傾向と逆になった。ここでは，一つの形式

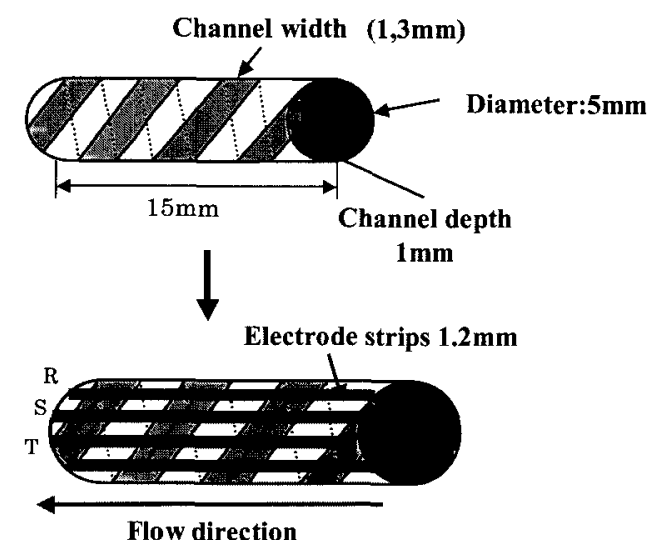

Fig. 19 Liquid crystal pump

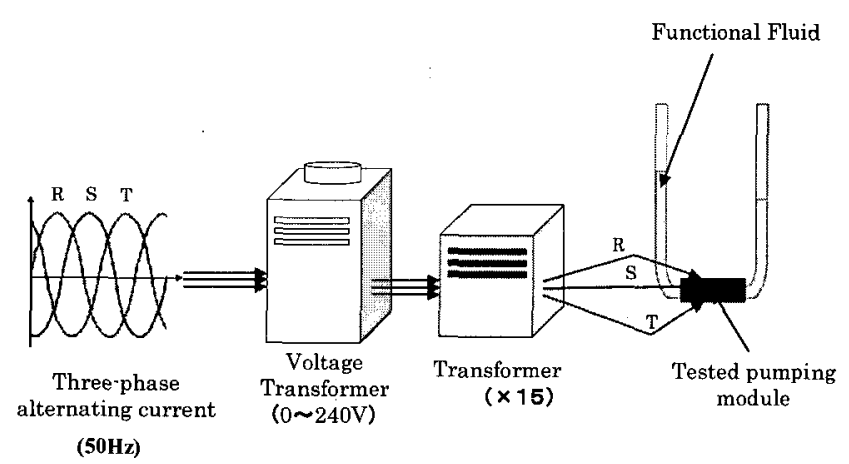

Fig. 20 Experimental apparatus 
のポンプについて述べたが，電場による液晶の流動を利 用したいろいろなポンプやアクチュエータ一が考えられ る.

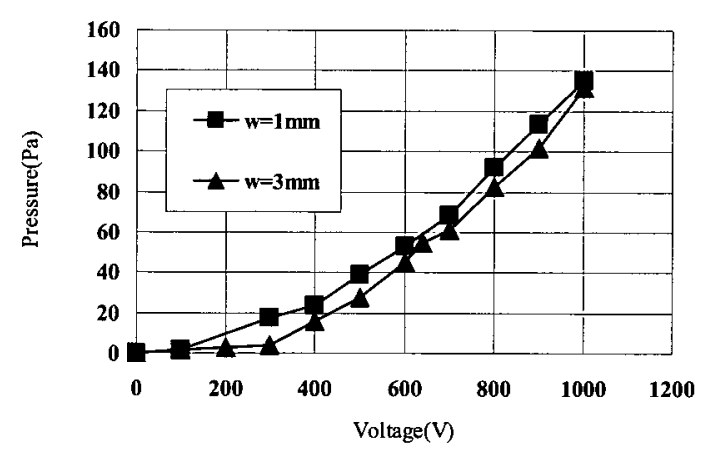

Fig. 21 Pressure without flow

\section{5.終わりに}

本解説では, 基本的な流れ場において，液晶に電場を 印加した場合の液晶の流動について述へ，特に非一様電 場強度のもとでの液晶の誘電泳動について実験結果を説 明した。次に, 円筒形の電極を試作し, 回転電場を印加 した場合の液晶流動について述べ，その回転流動を利用 したモータやポンプに関して説明した.ここでは $4 \sim 5$
種類の液晶を用いた実験を行なったが,さらに目的に応 じた物性値を持つ液晶の生成はある程度可能であり, 非 定常電場のもとでの液晶の流動メカニズムの解明ととも に, 今後の研究が期待される.

本実験を行うにあたり，液晶をご提供していただいた メルク粈に感謝の意を表す.

\section{参考文献}

1) 軍司昌秀：誘導泳動を用いた微小液滴の形成と融合, http:// www.washizu.t.u-tokyo.ac.jp/pdf/2002/gunji.pdf

2）寺坂澄孝, 三井和幸，他 5 名：EHD現象を応用したアク チュエータの開発，平成 16 年秋季フルードパワーシステム講 演会講演論文集, pp. $53-55$.

3 ) T.B.Jones, M.Gunji, M.Washizu, M.J.Feldman : Dielectrophoretic liquid actuation and nanodroplet formation, Journal of Applied Physics, Vol.89, No.2 (2001) pp.1441-1448.

4) 村田裕司, 築地徹浩：回転電場が混合液晶の流動に及ばす影 響, 日本機械学会2005 年度年次大会講演論文集, Vol. 2 (N 0.05-1), (2005) pp.63-64.

5 ）早川和慧，築地徹浩：機能性流体を用いたマイクロモータに 関する研究, 日本機械学会 2006 年度年次大会講演論文集, Vol.2 (N 0.06-1), (2006) pp.27-28.

6）築地徹浩, 鈴木健太, 村田裕司：液晶を用いたポンプモ ジュールに関する研究，日本機械学会九州支部講演論文集 No.068-1 (2006), pp.67-68. 


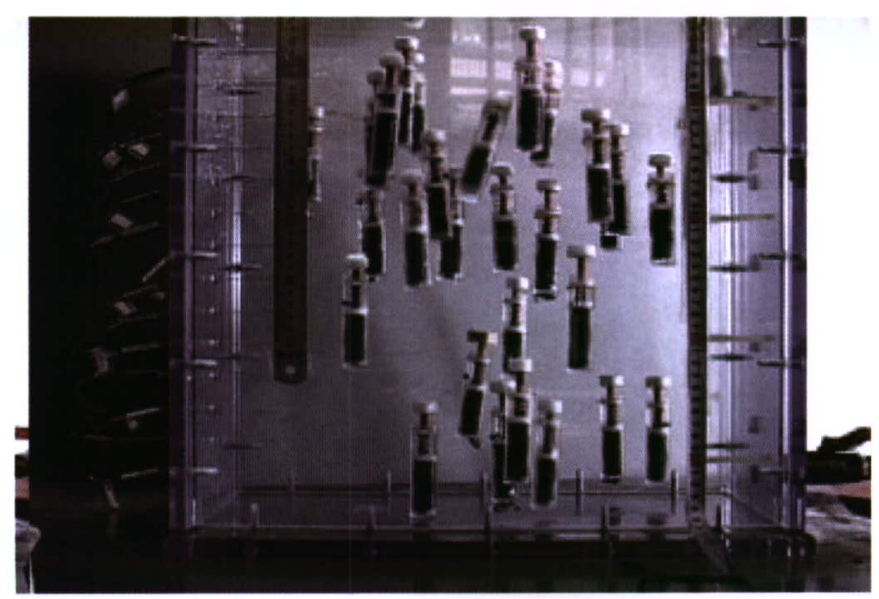

口絵 1 形状記憶合金とベローズを用いた逆熱対流素子

(大阪大学大学院工学研究科機械工学専攻 片岡 勲)

(本文86頁参照)

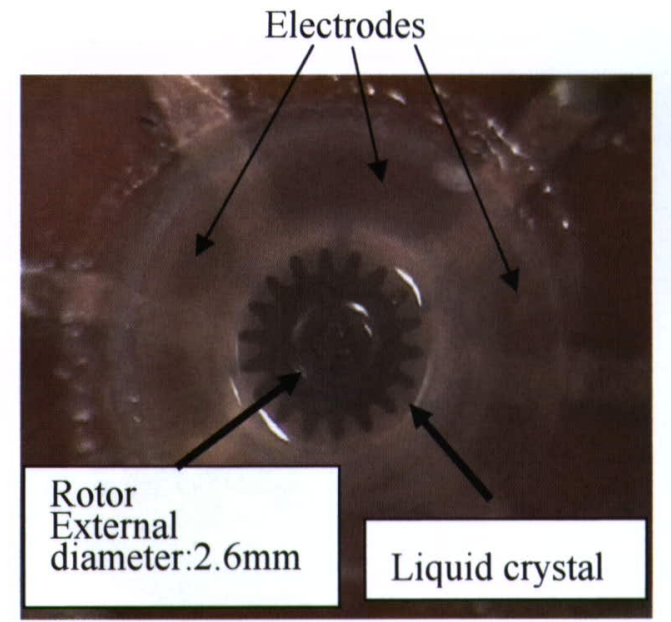

口絵2 液晶モータの内部：混合液晶（MJ0669）を使 用した場合, $1.3 \mathrm{kV}$ の相交流電圧を用いて約 250r.p.m.で回転する. 6 枚の電極を $0.2 \mathrm{~mm}$ 間 隔で設置し, ロータ外形は2.6mmである.

(上智大学理工学部機械工学科 築地 徹浩) (本文92頁参照)

Symmetrical axis

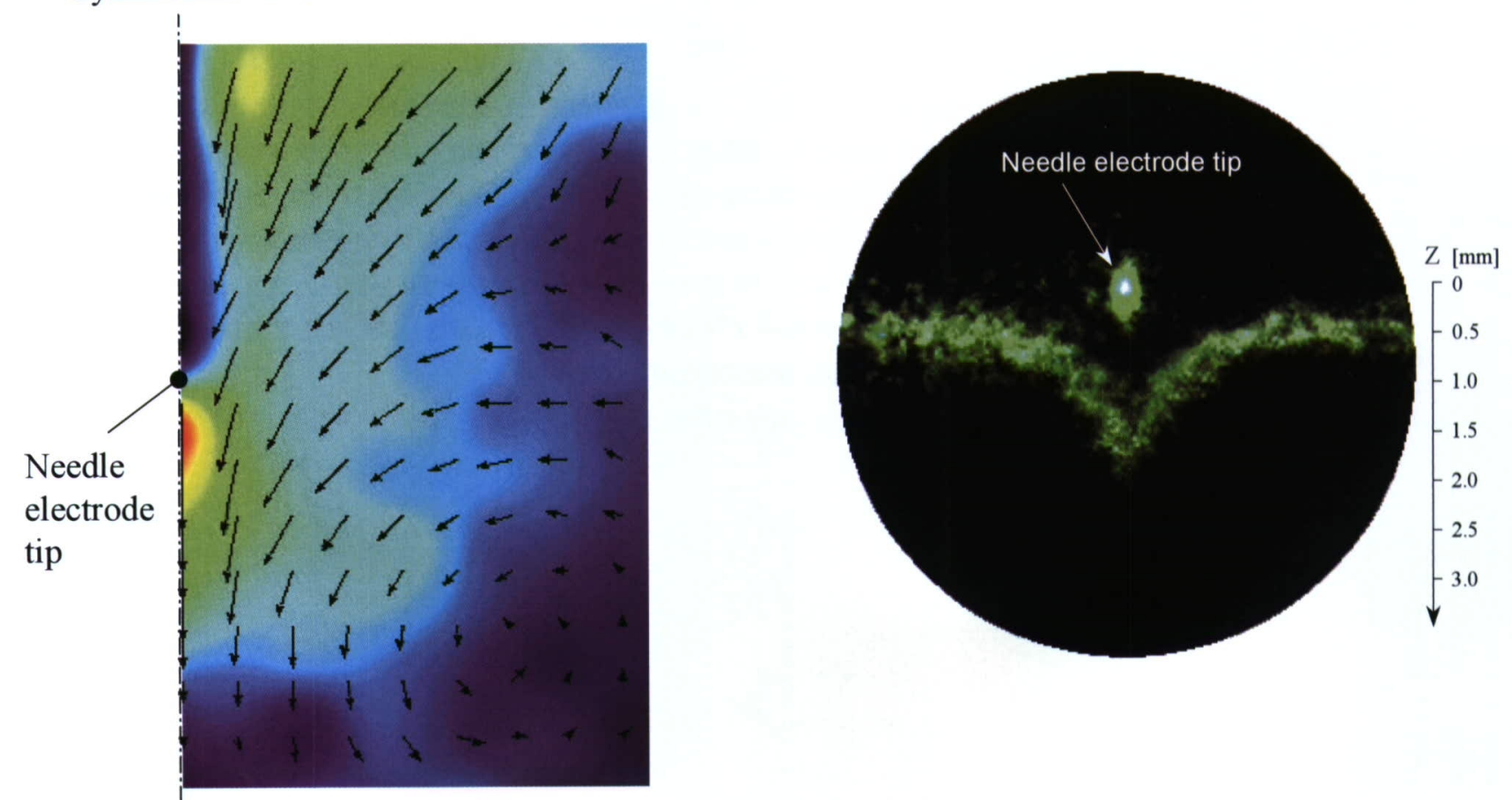

Plate electrode

口絵 3 針電極の先端から平板電極へ向かうイオン流に沿って誘起した気相EHD現象

: イオン風の（左）速度分布，（右）燐光トレーサによる可視化

(東海大学工学部電気電子工学科 大山 龍一郎) 